\title{
UJI VALIDITAS SKRINING STATUS GIZI NRS 2002 DENGAN ASESMEN BIOKIMIA UNTUK MENDETEKSI RISIKO MALNUTRITION DI RSUP Dr. SARDJITO YOGYAKARTA
}

\author{
M. Ridwan Ansari', Susetyowati', IDP Pramantara² \\ 1 Program Studi S1 Gizi dan Kesehatan FK UGM \\ 2Bagian Penyakit Dalam RSUP Dr. Sardjito Yogyakarta \\ ansari.ridwan@yahoo.co.id
}

\begin{abstract}
ABSTRAK
Saat ini alat skrining gizi yang dapat digunakan di rumah sakit jumlahnya cukup banyak, namun belum banyak penelitian yang bertujuan untuk mengetahui validasi alat-alat tersebut ketika digunakan pada masing-masing institusi. Penelitian ini dilakukan dengan rancangan cross-sectional. Pengambilan sampel dengan metode purposive sampling yang memenuhi kriteria inklusi dan eksklusi minimal sebanyak 101 orang. Skrining gizi dilakukan dengan cara observasi dan wawancara langsung dengan pasien, sedangkan asesmen gizi dilakukan dengan melihat data albumin dan TLC pada buku rekam medik pasien. Untuk melihat hubungan antar variabel dianalisis dengan uji Chi-square dan regresi logistik sedangkan untuk melihat nilai validitas NRS digunakan uji kontingensi tabel $2 \times 2$ dan uji korelasi melalui uji Spearman. Hasil penelitian menunjukkan bahwa pasien yang berisiko malnutrition berdasarkan NRS 2002 sebanyak 33,7 persen (34 orang) dan yang mengalami malnutrition berdasarkan albumin adalah 71,3 persen (72 orang) dan TLC 47,5 persen (48 orang). Nilai sensitivitas dan spesivisitas NRS 2002 berdasarkan albumin berturut-turut adalah 82,4 persen dan 65,7 persen, sedangkan nilai sensitivitas dan spesifisitas NRS 2002 berdasarkan TLC berturut-turut adalah 55,9 persen dan 50,7 persen. Terdapat korelasi yang signifikan antara skor NRS 2002 dengan kadar albumin (r: -0.238) namun tidak dengan TLC. Tidak ada hubungan yang signifikan antara skrining gizi NRS 2002 dengan TLC dan albumin ( $p$ value > 0,05 untuk kedua analisis). Namun didapatkan kecenderungan pada pasien dengan skor NRS $\geq 3$ (OR: $3.078,95 \% \mathrm{Cl}: 0.9-9.76)$, dan yang berada di bangsal penyakit dalam (OR: $5.330,95 \% \mathrm{Cl}: 1.48-19.09$ ), serta pasien yang tergolong lansia (OR:4.057, 95\% Cl: 1.08-15.14) mengalami kurang gizi berdasarkan albumin. Metode skrining status gizi NRS 2002 valid untuk mendeteksi risiko malnutrition di rumah sakit setelah dibandingkan dengan kadar albumin sebagai referensi.
\end{abstract}

Kata kunci: malnutrisi, skrining NRS 2002, albumin, TLC, status gizi

\section{ABSTRACT}

\section{VALIDITY TEST OF NRS 2002 NUTRITIONAL SCREENING USING BIOCHEMICAL ASSESSMENT TO DETECT THE RISK OF MALNUTRITION IN RSUP Dr. SARDJITO YOGYAKARTA}

Currently various nutritional screening tools have been used in hospitals, but only a few researches have been directed to determine the validation of the tools. This research was carried out using cross sectional observational study design. Purposive sampling method used to withdraw 101 subjects which met the minimum criteria for inclusion and exclusion. Nutritional screening was performed through observation and direct interview, whereas nutritional assessment carried out by evaluating albumin data and TLC from medical record. Chi square and logistic regression tests were applied to determine the relationship between variables. The validity of the NRS was analyzed using $2 \times 2$ contingency tables and Spearman correlation coefficient. This study found out that subjects who were at risk of malnutrition according to NRS 2002 were 33.7 per cent (34 subjects) and the malnourished based on albumin level was 71.3 per cent (72 subjects) and based on TLC 47.5 per cent (48 subjects). Sensitivity and specificity values of NRS based on albumin level were 82.4 per cent and 65.7 per cent, while their values based on TLC were $\mathbf{5 5 . 9}$ per cent and 50.7 per cent, respectively. There was a significant correlation between NRS 2002 and albumin $(r=-0.238 ; p<0.05)$ but not with TLC. There was no relationship between nutritional screening NRS 2002 with TLC and albumin ( $p>0.05)$. However, there was a trend obtained from patients with a NRS score $>3$ (OR: 3.078, 95\%Cl:0.9-9.76), from the internal medicine patients (OR: 5.330, 95\%Cl: 1.48-19.09), and from elderly patients (OR:4.057, $95 \% \mathrm{Cl}: 1.08-15.14$ ) that they became malnutrition based on albumin level. NRS 2002 screening tool was a valid method to detect risk of malnutrion in hospital as compared to albumin as a reference.

Keywords: malnutrition, NRS 2002, albumin, TLC, nutritional status 


\section{PENDAHULUAN}

M alnutrition iatrogenik adalah malnutrition energi protein akibat pengobatan dan perawatan yang didapat selama pasien berada di rumah sakit (RS). Survei menunjukkan bahwa prevalensi malnutrition iatrogenik relatif hampir merata, baik di RS daerah maupun RS pendidikan pada berbagai jenis penyakit dan status sosial ekonomi penderita, ${ }^{1}$ sehingga diperlukan upaya yang tepat untuk mencegah malnutrition ini. Salah satu cara yang dapat dilakukan adalah pembentukan Tim Dukungan Gizi (TDG) di RS. Penelitian Weinsier (1985) dan Hassel (1994) dalam Depkes RI tahun 2002², menunjukkan bahwa intervensi gizi oleh TDG dapat menurunkan angka kematian, lama rawat inap, dan rawat ulang berturut-turut hingga 23 persen, 11,6 persen dan 43 persen. Adapun konsep pelayanan TDG meliputi skrining, asesmen, diagnosis, intervensi, monitoring, dan evaluasi yang dikenal dengan Nutrition Care Process (NCP). NCP didesain untuk meningkatkan konsistensi dan kualitas perawatan pada pasien individu dan serta memprediksi outcome dari pasien. ${ }^{3}$

Banyak alat skrining gizi yang digunakan di RS, namun belum semua divalidasi pada tempat pelayanan kesehatan, populasi pasien tertentu, dan diteliti. Padahal untuk dapat menentukan alat yang cocok digunakan pada institusi, hal-hal tersebut penting untuk dipenuhi. ${ }^{4}$ Salah satu metode skrining gizi yang digunakan di rumah sakit adalah NRS 2002 (Nutritional Risk Screening 2002) yang didasarkan pada hasil eksperimen Clinical Controlled Trial yang mempunyai validasi baik, sederhana, cepat, memadukan penilaian dari faktor penyakit, faktor gizi (status gizi, asupan gizi, penurunan $\mathrm{BB}$, peningkatan kebutuhan gizi) dan faktor usia serta memiliki nilai sensitivitas, spesifitas dan nilai prediksi lebih baik dibanding satu indeks. ${ }^{5,6}$

Untuk mengetahui kemampuan metode skrining gizi yang subjektifitasnya tinggi, perlu dibandingkan dengan metode asesmen gizi yang objektif sehingga diperoleh gambaran status gizi secara akurat. Salah satu metode asesmen gizi yang biasa digunakan adalah penilaian status gizi berdasarkan kadar biokimiawi, baik melalui pemeriksaan protein visceral maupun fungsi imunologik. Salah satu pemeriksaan protein visceral yang paling sering digunakan adalah kadar albumin karena mudah dan murah. Serum albumin penting untuk mendiagnosis malnutrition protein, kadar albumin dan status gizi pasien penyakit akut dan kronis. ${ }^{7}$ Pemeriksaan fungsi imunologik yang biasa digunakan adalah indikator jumlah limfosit total (Total Lympocyte Count/TLC). TLC sangat sensitif pada pasien pada stadium kritis (critical ill) dan pembedahan. Lagi pula, TLC lebih cepat, murah, dan dapat menggambarkan keadaan kekurangan stimulasi mitogenik dan antigen akibat adanya infeksi atau peradangan. ${ }^{8,9}$ Pasien yang berada di bangsal penyakit dalam dan bedah merupakan kelompok pasien yang sangat rentan dengan kejadian infeksi atau gangguan fungsi imunitas karena seringkali berhubungan dengan kejadian ketidakcukupan konsumsi makanan. Berdasarkan pertimbangan di atas, maka peneliti tertarik untuk mengetahui validitas NRS 2002 yang dibandingkan dengan indikator asessmen status gizi berupa kadar albumin dan TLC sebagai kontrol pembanding sekaligus untuk mengetahui hubungan antara hasil skrining menggunakan NRS 2002 dengan hasil asesmen dari kadar albumin dan TLC di bangsal penyakit dan bedah.

\section{METODE PENELITIAN}

Jenis penelitian ini adalah observasi dengan rancangan cross-sectional. Penelitian dilakukan di Rumah Sakit RSUP Dr.Sardjito Yogyakarta pada bulan Februari-Mei 2011. Subjek penelitian adalah pasien baru (2x24 jam) yang dirawat inap di bangsal penyakit dalam dan bedah dengan kriteria berusia $>18$ tahun, tidak dalam keadaan hamil, compos mentis, mampu berkomunikasi dengan baik, dapat diukur tinggi badan dan berat badan, pada pasien dilakukan pemeriksaan biokimia meliputi albumin dan TLC. Pengambilan sampel dengan metode purposive sampling dan diperoleh responden sebanyak 101 orang. Variabel bebas penelitian adalah hasil skrining menggunakan NRS 2002, variabel terikat adalah hasil asesmen biokimiawi (gold standard) menggunakan TLC dan albumin (alb), sedangkan variabel pengganggu adalah jenis kelamin, tempat perawatan, jenis penyakit, dan usia. 
Dikatakan berisiko malnutrition jika skor NRS $2002 \geq 3$.Berdasarkan kadar albumin dan TLC (beturut-turut), pasien mengalami kurang gizi jika alb $<3,5 \mathrm{~g} / \mathrm{dL}$ dan TLC $\leq 1,5 \times 10^{9} / \mathrm{L} .24$ Uji chi-square digunakan untuk mengetahui hubungan antara variabel bebas dan terikat, uji regresi logistik untuk mengetahui hubungan keeratan faktor risiko terjadinya malnutrisi berdasarkan gold standard, sedangkan tabel kontingensi dan uji korelasi spearman digunakan untuk mengukur validitas NRS 2002 terhadap gold standard.

\section{HASIL}

Berdasarkan data karakteristik subjek penelitian (Tabel 1), diketahui bahwa distribusi pasien. Persentase responden perempuan lebih besar dibandingkan presentasi responden laki-laki. Sedangkan jumlah responden berusia lanjut lebih sedikit daripada jumlah responden dewasa.

Jumlah responden di bangsal penyakit dalam lebih banyak daripada jumlah pasien di bangsal bedah. Persentase responden yang terdiagnosis penyakit yang berhubungan dengan metabolisme protein lebih besar dibandingkan persentase responden yang tidak terdiagnosis penyakit yang berhubungan dengan metabolisme protein.

Data hasil skrining menggunakan NRS 2002 pada Tabel 2 diketahui bahwa jumlah pasien yang tidak berisiko dan berisiko malnutrition berdasarkan NRS 2002 masingmasing berjumlah 67 orang $(66,3 \%)$ dan 34 orang $(33,7 \%)$. Hasil skrining menggunakan NRS 2002 dan asesmen gizi berdasarkan kadar albumin dan TLC dapat dilihat pada Tabel 2.

Tabel 1

Karakteristik Subjek Penelitian

\begin{tabular}{lc}
\hline Variabel & $\mathrm{n}(\%)$ \\
\hline Jenis kelamin & \\
Laki-laki & $47(46,5)$ \\
Perempuan & $54(53,5)$ \\
Total & $101(100,0)$ \\
Usia & \\
Dewasa (18-59 th) & $72(71,3)$ \\
Lansia (>59 th) & $29(28,7)$ \\
Total & $101(100,0)$ \\
Bangsal & \\
Bedah & $16(15,8)$ \\
Penyakit dalam & $85(84,2)$ \\
Total & $101(100,0)$ \\
Jenis penyakit & \\
Penyakit metabolisme protein & $76(75,2)$ \\
Penyakit non-metabolisme protein & $25(24,8)$ \\
\hline Total & $101(100,0)$ \\
\hline
\end{tabular}


Tabel 2

Hasil Skrining Gizi NRS 2002 dan Asesmen Biokimia

\begin{tabular}{lcc}
\hline \multirow{2}{*}{ Variabel } & \multicolumn{2}{c}{ Jumlah } \\
\cline { 2 - 3 } & $\mathrm{n}$ & $\%$ \\
\hline NRS 2002 & 34 & 33,7 \\
Berisiko malnutrition & 67 & 66,3 \\
Tidak berisiko malnutrition & 101 & 100,0 \\
Total & & \\
Albumin & 72 & 71,3 \\
Malnutrition & 29 & 28,7 \\
Normal & 100 & 100,0 \\
Total & & \\
Total Limfosit Count & 48 & 47,5 \\
Gangguan fungsi imun & 53 & 52,5 \\
Normal & 101 & 100,0 \\
Total & & \\
\hline
\end{tabular}

Tabel 3

Hasil Analisis Karakteristik Responden dengan NRS 2002

\begin{tabular}{|c|c|c|c|c|c|}
\hline \multirow[t]{2}{*}{ Karakteristik } & \multicolumn{2}{|c|}{$\begin{array}{c}\text { NRS } 2002 \\
\text { (Risiko) }\end{array}$} & \multicolumn{2}{|c|}{$\begin{array}{c}\text { NRS } 2002 \\
\text { (Tidak Berisiko) }\end{array}$} & \multirow{2}{*}{$p$} \\
\hline & $\mathrm{n}$ & $\%$ & $n$ & $\%$ & \\
\hline \multicolumn{6}{|l|}{ Bangsal } \\
\hline - Penyakit dalam & 8 & 50,0 & 8 & 50,0 & $0,132^{*}$ \\
\hline - Bedah & 26 & 30,5 & 59 & 69,5 & \\
\hline \multicolumn{6}{|l|}{ Jenis Penyakit } \\
\hline - Metb_Protein & 25 & 32,8 & 51 & 67,2 & 0,776 \\
\hline - Non Metb_Protein & 9 & 36,0 & 16 & 64,0 & \\
\hline \multicolumn{6}{|l|}{ Umur } \\
\hline - Lansia & 22 & 30,5 & 50 & 69,4 & 0,298 \\
\hline - Dewasa & 12 & 41,3 & 17 & 58,6 & \\
\hline \multicolumn{6}{|l|}{ Jenis kelamin } \\
\hline - Laki-laki & 16 & 34,0 & 31 & 66,0 & 0,940 \\
\hline - Perempuan & 18 & 33,3 & 36 & 66,7 & \\
\hline
\end{tabular}


Tabel 4

Hasil Analisis Karakteristik Responden berdasarkan Asesmen Biokimia

\begin{tabular}{|c|c|c|c|c|c|c|c|c|c|c|}
\hline \multirow[t]{2}{*}{ Karakteristik } & \multicolumn{2}{|c|}{$\begin{array}{c}\text { Albumin } \\
\text { (Gizi kurang) }\end{array}$} & \multicolumn{2}{|c|}{$\begin{array}{l}\text { Albumin } \\
\text { (Gizi baik) }\end{array}$} & \multirow[t]{2}{*}{$p$} & \multicolumn{2}{|c|}{$\begin{array}{c}\text { TLC } \\
\text { (Gangguan } \\
\text { fungsi imun) }\end{array}$} & \multicolumn{2}{|c|}{$\begin{array}{c}\text { TLC } \\
\text { (Normal) }\end{array}$} & \multirow[t]{2}{*}{$p$} \\
\hline & $\mathrm{n}$ & $\%$ & $\mathrm{n}$ & $\%$ & & $\mathrm{n}$ & $\%$ & $\mathrm{n}$ & $\%$ & \\
\hline \multicolumn{11}{|l|}{ Bangsal } \\
\hline - Penyakit dalam & 65 & 76,4 & 20 & 23,6 & $0,008^{*}$ & 40 & 47,0 & 45 & 53,0 & 0,829 \\
\hline - Bedah & 7 & 45,7 & 9 & 56,3 & & 8 & 50,0 & 8 & 50,0 & \\
\hline \multicolumn{11}{|l|}{ Jenis Penyakit } \\
\hline - Metb_Protein & 57 & 75,0 & 19 & 25,0 & $0,150^{*}$ & 35 & 46,0 & 41 & 54,0 & 0,605 \\
\hline - Non Metb_Protein & 15 & 60,0 & 10 & 40,0 & & 13 & 52,0 & 12 & 48,0 & \\
\hline \multicolumn{11}{|l|}{ Umur } \\
\hline - Lansia & 26 & 89,7 & 3 & 10,3 & $0,010^{*}$ & 15 & 51,7 & 14 & 48,3 & 0,592 \\
\hline - Dewasa & 46 & 63,8 & 26 & 36,2 & & 33 & 45,8 & 39 & 54,2 & \\
\hline \multicolumn{11}{|l|}{ Jenis kelamin } \\
\hline - Laki-laki & 35 & 74,4 & 12 & 25,6 & 0,510 & 22 & 46,8 & 25 & 53,2 & 0,898 \\
\hline - Perempuan & 37 & 68,5 & 17 & 31,5 & & 26 & 48,2 & 28 & 51,8 & \\
\hline
\end{tabular}

Berdasarkan Tabel 3, diketahui bahwa variabel bangsal, jenis penyakit, umur dan jenis kelamin bukan merupakan counfounding factor yang mempengaruhi hasil analisis hubungan antara variabel bebas dan tergantung dalam penelitian ini, sehingga tanpa memperhitungkan confounding factor pun hasil analisis hubungan akan tetap valid. Namun demikian, dari Tabel 4 variabel bangsal, jenis penyakit dan umur memiliki nilai $p<0.25$ berdasarkan kadar albumin termasuk juga variabel skor NRS 2002. Sehingga variabel-variabel tersebut dapat dianalisis pola hubungan keeratannya atau kecenderungannya terhadap kejadian gizi kurang berdasarkan kadar albumin dengan menggunakan uji regresi logistik multivariat. Analisis regresi logistik ini digunakan untuk memprediksi kejadian gizi kurang berdasarkan konstanta masing-masing faktor risiko. Sebelum melakukan analisis regresi logistik, masingmasing variabel harus dibedakan mana yang dijadikan pembanding (Ref). Pembanding yang digunakan pada analisis ini adalah kategori yang dianggap tidak berisiko.

Sedangkan hubungan antara skrining gizi NRS 2002 dengan kadar albumin dapat dilihat pada Tabel 5. Hasil uji statistik menggunakan chi square dengan tingkat kepercayaan 95\% menunjukkan tidak ada hubungan yang bermakna antara hasil skrining gizi NRS 2002 dengan status gizi berdasarkan kadar albumin (bahwa $p>0,05$ ). Akan tetapi variabel skor
NRS ini akan bisa dimasukkan dalam analisis pola hubungan atau kecenderungan dengan kejadian gizi kurang bersama variabel umur dan jenis bangsal melalui uji multivariat regresi logistik. Berikut hasilnya dapat dilihat pada Tabel 6.

Dari hasil analisis didapatkan nilai Hosmer and Lemeshow's goodness of fit test dengan nilai $p$ sebesar 0,481 . Nilai kalibrasi persamaan dikatakan baik apabila nilai $\mathrm{p}$ hosmer dan lemeshow test $>0.05$, artinya persamaan yang didapatkan berdasarkan Tabel 6 mempunyai kalibrasi yang baik. ${ }^{46}$ Hasil akhir analisis multivariat regresi logistik menyatakan bahwa variabel yang berpengaruh terhadap kejadian gizi kurang terbesar berturut-turut adalah bangsal $(O R=5,330)$, umur $(O R=4,057)$, dan skor NRS 2002 (OR = 3,078). Pada pasien yang berada di bangsal penyakit dalam cenderung mengalami gizi kurang dengan risiko 5,330 kali lebih tinggi dibandingkan pasien yang berada di bangsal bedah. Pasien yang tergolong lansia memiliki kecenderungan 4,057 kali lebih berisiko mengalami gizi kurang dibandingkan pasien dewasa. Pasien yang memiliki skor NRS $\geq 3$ cenderung mengalami gizi kurang dibandingkan pasien yang memiliki skor NRS < 3 dengan peluang 3,078 kali lebih besar. Adapun hubungan antara skrining gizi NRS 2002 dengan TLC dapat dilihat pada Tabel 7. 
Tabel 5

Hubungan Skrining Gizi NRS 2002 dengan Kadar Albumin

\begin{tabular}{lcccccc}
\hline \multirow{2}{*}{ Skor NRS } & \multicolumn{2}{c}{$\begin{array}{c}\text { Albumin } \\
(\text { Malnutrition }\end{array}$} & $\begin{array}{c}\text { Albumin } \\
\text { (Normal) }\end{array}$ & p & $\begin{array}{c}\text { OR } \\
(95 \% \mathrm{Cl})\end{array}$ \\
\cline { 2 - 5 } & $\mathrm{n}$ & $\%$ & $\mathrm{n}$ & $\%$ & & \\
\hline Berisiko malnutrition & 28 & 82,3 & 6 & 17,7 & 0,080 & 2,439 \\
Tidak berisiko malnutrition & 44 & 65,6 & 23 & 34,4 & & $(0.883-6.736)$ \\
\hline
\end{tabular}

Tabel 6

Hasil Analisis Hubungan Kejadian Gizi Kurang berdasarkan Kadar Albumin

\begin{tabular}{llcccc}
\hline Variabel & $\beta$ & Wald & $p$ & OR & $95 \% \mathrm{Cl}$ \\
\hline NRS & 1,124 & 3,643 & 0,056 & 3,078 & $0,9-9,76$ \\
Bangsal & 1,673 & 6,607 & 0,010 & 5,330 & $1,48-19,09$ \\
Umur & 1,401 & 4,345 & 0,037 & 4,057 & $1,08-15,14$ \\
\hline B: Koefisien regresi, konstanta: -1.083, AUC: & $75.5 \%$, phosmer dan lemeshow test: 0.481
\end{tabular}

Tabel 7

Hubungan Skrining Gizi NRS 2002 dengan Total Lymfosit Count

\begin{tabular}{|c|c|c|c|c|c|c|}
\hline \multirow[t]{2}{*}{ Skor NRS } & \multicolumn{2}{|c|}{$\begin{array}{c}\text { TLC } \\
\text { (Gangguan } \\
\text { fungsi imun) }\end{array}$} & \multicolumn{2}{|c|}{$\begin{array}{c}\text { TLC } \\
\text { (Normal) }\end{array}$} & \multirow[t]{2}{*}{$p$} & \multirow[t]{2}{*}{$\begin{array}{c}\text { OR } \\
(95 \% \mathrm{Cl})\end{array}$} \\
\hline & $\mathrm{n}$ & $\%$ & $\mathrm{n}$ & $\%$ & & \\
\hline Berisiko malnutrition & 15 & 44,1 & 19 & 55,9 & 0,625 & 0,813 \\
\hline Tidak berisiko malnutrition & 33 & 49,3 & 34 & 50,7 & & $(0,355-1,864)$ \\
\hline
\end{tabular}

Tabel 8

Nilai r square, Sensitivitas, Spesifisitas dan Area Under Curve (AUC) Metode Skrining Gizi awal NRS 2002 terhadap Albumin dan TLC

\begin{tabular}{lccccc}
\hline & \multicolumn{5}{c}{ NRS 2002 } \\
\cline { 2 - 6 } & Sp (\%) & Se $(\%)$ & MSS (\%) & AUC (\%) & R-square \\
\hline Albumin & 82,4 & 65,7 & 148,1 & 58,3 & $-0,238^{*}$ \\
TLC & 55,9 & 50,7 & 106,6 & 52,6 & 0,043 \\
\hline${ }^{*}$ p value < 0.05 uji korelasi Spearman & & & &
\end{tabular}

Berdasarkan Tabel 7 menunjukkan tidak ada hubungan yang bermakna antara hasil skrining gizi NRS 2002 dengan status gizi berdasarkan kadar TLC $(p>0,05)$. Begitu pula dengan hasil analisis bivariat variabel karakteristik dengan NRS 2002 dan TLC menunjukkan hasil bahwa tidak ada variabel yang berpotensi menjadi counfounding factor dalam penelitian ini. Selain mengetahui hubungan antara hasil skrining gizi NRS 2002 dengan kadar albumin dan TLC, pada penelitian ini juga dilakukan uji validitas NRS 2002 terhadap kadar albumin dan TLC. Adapun hasil perhitungan nilai koefisien korelasi spearman atau R-square, sensitivitas dan spesifisitas NRS 
2002 terhadap gold standart berupa albumin dan TLC dapat dilihat pada Tabel 8.

Dari Tabel 8 dapat dilihat nilai sensitivitas dan spesifisitas skrining gizi NRS 2002 terhadap albumin berturut-turut adalah 82,4 persen dan 65,7 persen. Nilai MSS diperoleh dari penjumlahan nilai sensitivitas dan spesifisitas. Dilihat dari nilai MSS-nya metode skrining gizi NRS 2002 adalah sebesar 148,1 persen untuk penilaian gizi berdasarkan albumin. Berdasarkan hasil uji korelasi spearman, terdapat korelasi yang signifikan antara skor NRS 2002 dengan kadar albumin, walaupun dengan koefisien korelasi yang rendah.

\section{BAHASAN}

Berdasarkan penelitian multicenter pada 26 RS di Eropa ${ }^{10}$, ditemukan pasien yang berisiko malnutrition sebanyak 1647 pasien (32,6\%) dari total responden 5051 pasien, sedangkan penelitian di Indonesia, menunjukkan data dari 201 pasien yang masuk rumah sakit, 82 orang $(40,8 \%)$ diantaranya berisiko mengalami malnutrition. ${ }^{11}$ Berdasarkan data dari beberapa penelitian di atas, prevalensi malnutrition pasien di rumah sakit menggunakan NRS 2002 relatif hampir sama. Namun demikian,metode skrining NRS 2002 ini belum diketahui kemampuannya dalam merepresentasikan hasil asesmen gizi yang valid dan reliabel. Skrining dan asesmen gizi merupakan istilah atau hal yang berbeda tujuan dan hasil akhirnya. Skrining merupakan langkah awal untuk mengindentifikasi karakteristik pasien yang berisiko dan berhubungan dengan faktor gizi ${ }^{12,13}$, sedangkan asesmen gizi merupakan sebuah pemeriksaan komprehensif yang dilakukan untuk menetapkan status gizi (pemeriksaan riwayat medis, asupan, pemeriksaan fisik, pemeriksaan antropometri dan data biokimia). ${ }^{14}$

Pada pelayanan kesehatan komunitas seperti di rumah sakit, melakukan asesmen gizi secara lengkap merupakan hal yang tidak efektif karena berdampak pada biaya dan waktu yang harus dihabiskan, sedangkan metode skrining adalah sebuah alat yang murah dan efektif untuk mendeteksi malnutrition. ${ }^{15}$ Suatu metode skrining dikatakan sebagai metode yang baik jika alat tersebut dapat digunakan secara cepat, mudah, sederhana dan dapat digunakan oleh tenaga kesehatan ${ }^{16}$, serta memadukan parameter subjek dan objektif (multi-parameter) untuk memprediksikan kemungkinan dampak buruk atau keberhasilan karena faktor gizi sehingga dapat diberikan dukungan gizi secara tepat dan cepat untuk menghindari komplikasi dan peningkatan lama rawat inap. ${ }^{5}$

Proporsi pasien yang berisiko malnutrition berdasarkan skrining NRS 2002 ini jauh lebih sedikit dibandingkan dengan proporsi pasien yang berstatus gizi kurang berdasarkan albumin. Padahal yang diharapkan adalah jumlah pasien yang berisiko malnutrition dengan jumlah yang berstatus gizi kurang berdasarkan albumin minimal sama atau bahkan lebih banyak. Hal ini menunjukkan bahwa hasil skrining gizi tidak dapat merepresentasikan hasil asesmen gizi, sehingga pasien yang baru masuk rumah sakit tetap harus melakukan asesmen gizi untuk menentukan status gizi yang lebih akurat sebagai dasar menentukan intervensi gizi.Hasil skrining gizi hanya dapat digunakan untuk menentukan skala prioritas, pasien mana yang lebih dulu dilakukan tindakan intervensi selanjutnya mengingat jumlah SDM ahli gizi di rumah sakit masih kurang. Hasil ini sesuai dengan penelitian yang dilakukan oleh Simanjuntak yang juga menemukan proporsi pasien berisiko menurut NRS 2002 jauh lebih sedikit dibandingkan albumin yaitu 44,6 persen (NRS 2002) dan 71,8\% (albumin). ${ }^{17}$

Berdasarkan Tabel 2 diketahui bahwa sebagian besar responden dalam penelitian ini mengalami gizi kurang berdasarkan albumin dengan jumlah 72 orang $(71,3 \%)$ dan yang berstatus gizi baik sebesar 29 orang $(28,7 \%)$. Dengan demikian prevalensi malnutrition di rumah sakit masih cukup tinggi. Beberapa faktor yang mempengaruhi hal tersebut antara lain asupan energi yang tidak adekuat, lamanya pasien dirawat inap, pasien dengan penyakit noninfeksi, dan bentuk makanan khusus yang diperoleh pasien. ${ }^{19}$ Malnutrition dapat timbul sejak sebelum dirawat di rumah sakit yang karena penyakitnya atau masukan zat gizi yang tidak cukup, namun tidak jarang pula malnutrition ini timbul selama dirawat inap..$^{20}$ Weisner melaporkan 48 persen status gizi kurang terjadi waktu pasien masuk, setelah dirawat dua minggu meningkat menjadi 69 persen. ${ }^{1}$ Untuk mencegah progresivitas masalah malnutrition ini perlu dilakukan skrining gizi untuk memprediksi kemungkinan dampak buruk 
atau keberhasilan yang dapat terjadi karena faktor gizi. ${ }^{21}$ Perlunya skrining gizi awal untuk mengidentifikasi pasien yang berisiko malnutrition karena malnutrition berhubungan dengan meningkatnya kesakitan dan kematian di rumah sakit, meningkatkan lama rawat inap, dan biaya rumah sakit. Identifikasi pasien malnutrisi sangat penting dilakukan untuk mengetahui intervensi gizi yang tepat. ${ }^{22}$

Prevalensi malnutrition yang besar pada penelitian ini kemungkinan karena sebagian besar responden pada penelitian terdiagnosis penyakit-penyakit yang berhubungan dengan metabolisme protein.Sebanyak 57 pasien $(75 \%)$ (Tabel 4) yang mengalami gizi kurang berdasarkan nilai albumin terdiagnosis penyakit yang berhubungan dengan metabolisme protein. Hal ini berpengaruh terhadap kadar albumin responden, karena penyakit yang berhubungan dengan metabolisme protein seringkali berhubungan dengan kondisi penyakit yang kronis dan albumin merupakan salah satu indikator perubahan biokimiawi yang paling sensitif terhadap penyakit-penyakit yang kronis. ${ }^{23}$ Selain itu, faktor usia juga turut berpengaruh terhadap besarnya prevalensi malnutrisi berdasarkan kadar albumin pada penelitian ini. Pada penelitian ini, responden yang tergolong lansia dan mengalami gizi kurang sebanyak 29 orang $(89,7 \%)$ dari total responden. Faktor usia dapat berpengaruh secara tidak langsung terhadap sintesis albumin, pada orang-orang yang sudah lansia banyak yang mengalami penurunan intake atau asupan yang disebabkan baik oleh faktor motorik atau fisiologis akibatnya berpengaruh terhadap penurunan asupan protein dalam tubuh yang merupakan sumber utama sintesis albumin dalam tubuh. ${ }^{24}$ Menurut Harris dkk. kadar albumin akan menurun kurang $0,8 \mathrm{~g} / \mathrm{dL}$ setiap 1 dekade (10 th) setelah berusia lebih dari 60 tahun. ${ }^{25}$

Dari Tabel 2 juga dapat diketahui bahwa sebanyak 52,5 persen (53 orang) menggunakan indikator TLC tergolong normal dan sisanya 47,5 persen (48 orang) mengalami gangguan fungsi imun. Terdapat perbedaan antara hasil asesmen dengan menggunakan albumin dan TLC, sebagian besar responden pada penelitian ini tergolong status gizi kurang $(71,3 \%)$ menurut kadar albumin, sedangkan menurut kadar TLC responden tergolong normal (52,5\%). Perbedaan ini kemungkinan disebabkan kemampuan TLC untuk mendeteksi responden yang benar tergolong normal (sensitivitas) dan kemampuan TLC untuk mendeteksi responden yang benar-benar mengalami deplesi jaringan atau gangguan fungsi imun (spesifisitas) rendah, sedangkan kadar albumin memiliki nilai sensitivitas dan spesifisitas yang lebih baik dibandingkan TLC. ${ }^{24}$ Lemahnya validitas TLC ini dipengaruhi oleh berbagai faktor, diantaranya: stress, sepsis, infeksi akut dan kronik, uremia, neoplasia, dan penggunaan obat-obatan streoid. ${ }^{24}$

Hasil uji statistik menggunakan Chi-square dengan tingkat kepercayaan 95\% menunjukkan tidak ada hubungan yang bermakna antara hasil skrining gizi NRS 2002 dengan status gizi berdasarkan kadar albumin (bahwa $p>0.05$ ). Hasil penelitian ini serupa dengan penelitian yang dilakukan oleh Simanjutak, yang menyatakan bahwa skrining gizi NRS 2002 tidak memiliki hubungan yang signifikan dengan asesmen biokimia (kadar albumin dan hemoglobin). ${ }^{17}$ Perbedaan penelitian ini adalah sampel respoden yang diambil dari bangsal saraf. Penelitian Bauer dkk yang membandingkan skrining gizi NRS 2002 dan SGA dengan kadar albumin juga melaporkan hasil serupa yaitu tidak ada hubungan yang signifikan antara skrining gizi NRS 2002 dan SGA dengan kadar albumin. ${ }^{27}$

Kelemahan penelitian ini adalah terdapatnya beberapa responden yang tidak mengetahui berat badannya sebelum masuk rumah sakit atau tidak pernah menimbang berat badannya dalam beberapa bulan terakhir, sehingga tidak mengetahui laju perubahan berat badan aktual yang terjadi. Hal ini dapat mempengaruhi hasil skoring skrining untuk menentukan responden berisiko atau tidak mengalami malnutrition. Analisis pola hubungan atau kecenderungan antara variabel karakteristik responden dengan kejadian gizi kurang melalui uji multivariat regresi logistik dapat dilihat pada Tabel 6 .

Berdasarkan dari Tabel 6 menunjukkan terdapat kontribusi variabel jenis bangsal, umur, dan skor NRS terhadap kejadian malnutrition berdasarkan kadar albumin. Ketiga hal tersebut dapat dijelaskan sebagai berikut. Pertama, sebagian besar responden yang berada di bangsal penyakit dalam banyak terdiagnosis penyakit degeneratif atau kronis yang sudah melewati proses yang panjang, padahal albumin 
merupakan indikator yang sangat baik untuk menentukan status gizi pasien yang terdiagnosis penyakit-penyakit kronis karena serum albumin memiliki masa paruh yang cukup lama sekitar 18 hari.24,30Kedua, pasien yang tergolong lansia (elderly), sehingga lebih berisiko mengalami gizi kurang dibandingkan pasien yeng berusia $<60$ tahun. Rauscher menyatakan bahwa faktor-faktor yang mendukung terjadinya malnutrition pada golongan lansia antara lain terjadinya penurunan fungsi fisiologis termasuk penurunan sintesis albumin dalam tubuh, keterbatasan fisik dan mobilitas, ketidakcukupan asupan makanan terkait dengan penurunan fungsi mekanis, faktor-psikosial ekonomi yang mendukung terjadinya malnutrition pada golongan lansia. ${ }^{31}$ Hal ini sesuai dengan paparan Agustina dkk. yang menerangkan bahwa pada kelompok lansia prevalensi malnutrition sangat tinggi. Malnutrition terjadi pada paling tidak setengah dari pasien lansia di rumah sakit yang berhubungan dengan penyakit yang akut dan progresif. Kondisi malnutrisi dapat menyebabkan rendahnya respon imun pada lansia. Malnutrition erat kaitannya dengan penurunan proliferasi sel limfosit, penurunan proliferasi sel limfosit, penurunan keluaran sitokin, dan penurunan respons terhadap vaksinasi. ${ }^{32}$

Ketiga, pada pasien yang memiliki skor NRS $2002 \geq 3$ lebih cenderung mengalami gizi kurang dibandingkan dengan pasien yang memiliki skor NRS < 3. Hal ini terjadi karena komponen pertanyaan skrining NRS 2002 memang didesain untuk mengidentifikasi terjadinya protein energi malnutrisi (PEM) dan memprediksi perkembangan memburuknya status gizi pasien di masa mendatang. ${ }^{28}$ Sehingga pasien yang memiliki skor NRS lebih tinggi dari 3 akan lebih menggambarkan terjadinya malnutrisi dan risiko memburuknya status gizi pasien di masa mendatang.

Berdasarkan Tabel 7 menunjukkan tidak ada hubungan yang bermakna antara hasil skrining gizi NRS 2002 dengan status gizi berdasarkan kadar TLC $(p>0,05)$. Begitu pula dengan hasil analisis bivariat variabel karakteristik dengan NRS 2002 dan TLC menunjukkan hasil bahwa tidak ada variabel yang berpotensi menjadi counfounding factor dalam penelitian ini. Hasil penelitian ini berbeda dengan penelitian yang dilakukan oleh Cereda yang membandingkan metode skrining gizi Geriatric Nutritional Risk Index (GNRI) dengan TLC.Cereda menyatakan ada hubungan yang bermakna antara metode skrining GNRI dengan hasil asesment TLC. ${ }^{33}$ Bedanya dengan penelitian Cereda ini yang menjadi subjek penelitian adalah para lansia atau subjek yang berusia $>60$ tahun. Perbedaan ini kemungkinan disebabkan karakteristik subjek pada penelitian yang berusia > 60 tahun. Menurut beberapa pustaka, umur dapat berpengaruh terhadap kadar TLC dalam tubuh. 34,35 Hal ini terkait dengan mekanisme fisiologis, semakin lanjut usia maka akan terjadi penurunan induksi proliferasi lymfosit dalam tubuh selain itu juga berhubungan dengan penurunan aktifitas thymulin. ${ }^{36,37}$ Kadar TLC pada lansia cenderung mengalami penurunan dibandingkan pasien yang bukan lansia. Selain itu, metode skrining gizi GNRI juga menggambarkan keadaan serum albumin dalam tubuh. Albumin berhubungan dengan terjadinya penurunan TLC. Seltzer dkk., menyatakan bahwa penurunan serum albumin ( $<3,5 \mathrm{~g} / \mathrm{dL}$ ) menunjukkan hubungan yang signifikan dengan penurunan TLC dan risiko terjadinya mortalitas 6 kali lebih besar. ${ }^{38}$ Perubahan pada fungsi sistem imun akan berpengaruh terhadap respon terjadinya infeksi dan akan memicu terjadinya protein wasting dan malnutrition. ${ }^{39}$ Keadaan hypoalbuminemia adalah suatu keadaan yang mengindikasi terjadinya protein wasting secara umum, sehingga metode skrining gizi GNRI lebih menggambarkan status gizi berdasarkan TLC.

Pada penelitian ini, hasil hubungan yang tidak signifikan antara skrining gizi NRS 2002 dengan TLC tidak dapat dikaitkan oleh pengaruh distribusi usia, karena proporsi antara responden lansia yang mengalami gizi kurang dan respoden dewasa yang mengalami gizi kurang jumlahnya relatif sama yaitu 51,7 persen dan 45,8 persen. Jika dikaitkan dengan proses terjadinya malnutrition dan infeksi, hubungan yang tidak signifikan ini dapat dijelaskan sebagai berikut. Pada bagian sebelumnya sudah dijelaskan bahwa hubungan antara malnutrition dan terjadinya infeksi dalam tubuh manusia masih terjadi perdebatan, apakah infeksi yang terjadi lebih dulu atau malnutrition yang lebih dulu. Menurut Asiah, yang menerangkan bahwa sinergisme antara infeksi dan malnutrition menyampaikan bahwa infeksi yang akan mengakibatkan malnutrisi dan 
malnutrition menyebabkan kerentanan terhadap terjadinya infeksi. ${ }^{40}$ Malnutrition yang disertai infeksi akan memperburuk derajat infeksi yang terjadi serta mengakibatkan terjadinya infeksi berulang. Malnutrition berat akan menghambat imunitas tubuh terhadap infeksi, merusak barrier perlindungan kulit dan membran mukosa serta menurunkan jumlah dan kapasitas fagositosis leukosit sebagai bagian dari sistem imunitas tubuh, sehingga memudahkan terjadinya infeksi. Begitu juga menurut Fatimah, yang menyatakan bahwa pasien yang mengalami infeksi berat akan mempengaruhi terjadinya malnutrisi rumah sakit karena peningkatan metabolisme tubuh, sehingga kebutuhan akan intake makanan akan meningkat pula. Pasien dengan keadaan infeksi akan mengalami anoreksia sehingga pasien tidak dapat menghabiskan makanan yang tersedia dengan demikian intake makanan tidak terpenuhi dan pasien akan mengalami penurunan status gizi. ${ }^{41}$

Dikaitkan dengan hasil yang tidak signifikan ini, maka akan menunjukkan bahwa infeksilah yang terjadi lebih dulu. Parameter rendahnya TLC lebih merefleksikan keadaan yang akut terjadinya ketidakcukupan asupan protein dibandingkan serum albumin yang lebih menunjukkan terjadinya ketidakcukupan asupan protein yang kronis dalam tubuh..$^{42} \mathrm{Hal}$ ini berarti responden yang mengalami penurunan TLC dalam penelitian ini belum sepenuhnya mengalami keadaan yang benar-benar malnutrisi. Terjadinya penurunan TLC pada responden tersebut belum sepenuhnya menginduksi terjadinya anorexia yang panjang dan peningkatan kebutuhan yang menyebabkan terjadinya malnutrisi. Apalagi skrining dilakukan maksimal 2×24 jam setelah pasien masuk rumah sakit. Sehingga skrining gizi NRS 2002 tidak dapat menggambarkan status gizi berdasarkan TLC dalam penelitian ini.Selain mengetahui hubungan antara hasil skrining gizi NRS 2002 dengan kadar albumin dan TLC, pada penelitian ini juga dilakukan uji validitas NRS 2002 terhadap kadar albumin dan TLC.

Dari Tabel 8 dapat dilihat nilai sensitivitas dan spesifisitas skrining gizi NRS 2002 terhadap albumin berturut-turut adalah 82,4 persen dan 65.7 persen. Nilai MSS diperoleh dari penjumlahan nilai sensitivitas dan spesifisitas. Dilihat dari nilai MSS-nya metode skrining gizi NRS 2002 adalah sebesar 148,1 persen untuk asesmen gizi berdasarkan albumin. Berdasarkan Budiarto, sensitivitas dan spesifisitas metode skrining NRS 2002 terhadap albumin masuk dalam golongan cukup baik karena hasil sensitivitasnya dan spesifitasnya > 60 persen. ${ }^{43}$ WHO memberikan persyaratan minimal sensitivitas dan spesifisitas metode skrining terhadap semua asesmen gizi adalah sebesar 35 persen dan 70 persen, artinya sensivitas NRS 2002 dalam penelitian ini sudah memenuhi kriteria minimum sedangkan spesifisitasnya hampir memenuhi kriteria minimum. ${ }^{44}$ Penelitian uji validitas NRS 2002 juga dilakukan oleh Simanjutak, hasil uji validitasnya bahkan lebih kecil dibandingkan hasil uji validitas pada penelitian ini yang menyatakan sensitivitas dan spesifitasnya berturut-turut adalah 53,7 persen dan 43,97 persen. ${ }^{17}$ Penelitian ini juga menjadikan albumin sebagai gold standart, namun bedanya adalah penelitian ini dilakukan di bangsal syaraf dan dibandingkan dengan metode skrining lain yaitu MUST. Dari Tabel 8 tersebut juga diketahui bahwa Area Under Curve (AUC) metode skrining NRS 2002 terhadap albumin adalah sebesar 58,3 persen. Menurut Dahlan, dengan hasil AUC sebesar 58,3 persen maka skrining NRS 2002 tergolong memilki kekuratan tes yang lemah (60\%-70\%). ${ }^{46}$ Hasil ini berbeda dengan penelitian yang dilakukan oleh Sugiro yang menilai AUC NRS 2002 berdasarkan SGA adalah sebesar 66,3 persen. ${ }^{11}$

Nilai koefisien korelasi spearman menunjukkan korelasi yang signifikan dengan nilai rho negatif. Hal ini menunjukkan bahwa semakin tinggi Albumin semakin rendah skor NRS 2002 yang berarti semakin tidak berisiko mengalami malnutrition.

\section{SIMPULAN DAN SARAN}

\section{Simpulan}

Metode skrining NRS 2002 merupakan metode skrining yang valid untuk mendeteksi risiko mengalami malnutrition pada pasien di rumah sakit. Hal ini ditunjukkan dengan nilai sensitivitas dan spesifitas yang tergolong baik berdasarkan kriteria dari WHO untuk skrining gizi. Hasil uji korelasi juga menunjukkan ada hubungan yang signifikan walaupun dengan koefisien rho yang rendah. Tidak ada hubungan antara skrining gizi NRS 2002 dengan asesmen berdasarkan kadar albumin dan TLC. Namun, 
terdapat kecenderungan terjadinya gizi kurang berdasarkan albumin pada pasien yang berada di bangsal penyakit dalam dengan risiko 5,33 kali lebih tinggi dibandingkan pasien yang berada di bangsal bedah. Pasien yang tergolong lansia memiliki kecenderungan 4,05 kali lebih berisiko dibandingkan pasien dewasa. Pada pasien yang memiliki skor NRS $\geq 3$ cenderung mengalami gizi kurang dibandingkan pasien yang memiliki skor NRS $<3$ dengan peluang 3,07 kali lebih besar.

\section{Saran}

Skrining gizi di rumah sakit tetap perlu dilakukan untuk menentukan prioritas, pasien mana yang akan diintervensi lebih dulu. Asesmen gizi pada pasien baru masuk rumah sakit tetap harus dilaksanakan untuk menentukan status gizi yang lebih akurat dan penentuan intervensi gizi secara tepat. Perlunya dilakukan penelitian lain yang menggunakan alat skrining gizi khusus dengan subjek dengan jenis penyakit dan bangsal tertentu. Hal ini dimaksudkan untuk melihat ketepatan penggunaan alat skrining tersebut mendeteksi malnutrition berdasarkan jenis penyakit dan bangsal tertentu.

\section{RUJUKAN}

1. Soegih,R. Pola Penanganan Kasus Gizi Di Puskesmas dan Rumah Sakit. Jakarta: Perhimpunan Nutrisi Enteral Dan Parenteral Indonesia, 1997

2. Depkes RI. Buku Pedoman Pelayanan Gizi Rumah Sakit. Jakarta: Depkes $\mathrm{Rl}, 2009$.

3. American Dietetic Association. The Nutrition Care Process. In: Nutrition Diagnosis: A Critical step in the Nutrition Care Process. .New York: ADA, 2006.

4. Anthony P. Nutrition screening tools for hospitalized patients. Journal Nutrition in Clinical Practice 2008, 23(4):373-382.

5. Meyer R. Espen Nutritional Support Recommendations. Istambul: ESPEN, 2006.

6. Keller $\mathrm{H}$, Margaret $\mathrm{H}$ and Sharon W.The Development Of Seniors In The Community : Risk Evaluation For Eating And Nutrition (SCREEN). Canadian
Journal Of Dietetic Practice Research 2000,61(2): 67-72.

7. Tierney LM, Mc Phee SJ and Papadakis MA. Current Medical Diagnosis and Treatment. New York : Mc Graw-Hill, 2004.

8. Dominioni, D. Predictive Indices For The Identification Of High-Risk Patients. European Surgical Research.1986;18(34):201-206.

9. Seltzer $\mathrm{MH}$, Fletcher HS, Slocum BA. Instant Nutritional Assessment In The Intensive Care Unit. Journal Parenteral Enteral Nutr.1981; 5(1):70-72.

10. Sorensen J, Kondrup J, Prokupowicz J. Euro OOPS : An International Multicentre Study to Implement Nutritional Risk Screening and Evaluate Clinical Outcome. Clinical Nutrition. 2008; 27(3):340-349.

11. Sugiro, AG. Perbandingan Metode NRS 2002 dan MST terhadap Asesment Gizi pada pasien penyakit dalam di RSUP Dr. Sardjito Yogyakarta. Skripsi: Yogyakarta: Universitas Gadjah Mada, 2010

12. Barrocas A, Bistrian BR, Blackburn GL, Chernoff R, Lipschitz DA, Cohen D et al. Appropriate and effective use of the NSI Checklist and Screens. Journal American Diet Assoc.1995;95(6): 647-648.

13. Edington J, Boorman J, Durrant ER. Prevalence of Malnutrition On Admission To Four Hospitals in England. The Malnutrition Prevalence Group. American Journal Clin Nutr.1999,19(3):191-195.

14. Charney P. Nutrition Screening And Assessment In Older Adults. Today's Dietician. 2005:10-22.

15. Schneider $\mathrm{H}$. Use Of Nutritional Scores To Predict Clinical Outcomes In Chronic Diseases. Nutritional Review 2000, 58315838.

16. Kruizenga MK, Maurits WVT, Jaap CS. Effectiveness and Cost Effectiveness of Early Screeningand Treatment of Malnutrished Patients. American Journal of Clinical Nutrition 2005;82(5):10821089.

17. Simanjutak, T. Hubungan Skrining Gizi NRS 2002 Dan MUST Dengan Asesment Biokimia Pada Pasien Bangsal Penyakit Dalam Dan Syaraf RSUP Dr. Sardjito Yogyakarta. Skripsi. Yogyakarta: Universitas Gadjah Mada, 2010. 
19. Kusumayanti IGA, Hamam $\mathrm{H}$, Susetyowati. Faktor-Faktor yang mempengaruhi Kejadian Malnutrisi Pasien Dewasa di Ruang Rawat Inap Rumah Sakit. Jurnal Gizi Klinik Indonesia 2004;1 (1):8-15.

20. Dwiyanti D, Hadi H, Susetyowati. Pengaruh Asupan Makanan Terhadap Kejadian Malnutrisi Rumah Sakit. Jurnal Gizi Klinik Indonesia 2004;1(1):1-7.

21. Isnawati. Konsep Pelayanan Gizi Di Rumah Sakit (Asuhan Gizi Klinik) Dalam Pelatihan Peningkatan Mutu Pelayanan Gizi. Semarang :Depkes Rl, 2005.

22. Singh HMD, Watt KMD, Veitch RMD. Malnutrition Is Prevalent In Hospitalized Medical Patients: Are Housestaff Identifying The Malnourished Patient? Nutrition 2005;22(4):350-354.

23. Mears, E. Nutritional Assessment An Opportunity For Laboratorians To Improve Health Care. S.I: Lab Advancing Health Care, 2005

24. Gibson, RS. Principles Of Nutrition Asesment. New York: Oxford University Press, 1990

25. Harris DC, Yuill E, Chesher DW. Correcting acidosis in hemodialysis: Effect on phosphate clearance and calcification risk. J Am Soc Nephrol. 1995;6:1607-1612.

27. Bauer JM, Vogl $T$, Wicklein $S$. Comparison of The Mini Nutritional Assessment, Subjective Global Assessment, And Nutritional Risk Screening (NRS 2002) For Nutritional Screening And Assessment In Geriatric Hospital Patients. Zeitschrift Fur Gerontologie Und Geriatrie. 2005;38 (5):322-327.

28. Kondrup J, Allison SP, Elia M. ESPEN Guidelines for nutrition Screening 2002. Clinical Nutrition 2003; 22(4):415-421.

30. Omran ML, Morley JE. Assessment of Protein Energy Malnutrition in Older Persons, Part l: History, Examination, Body Composition, And Screening Tools .Journal of Nutrition. 2000; 16 (1):50-63.

31. Rauscher, C. Malnutrition Among The Elderly. Canadian Family Physcian .1993;39:1395-1403.

32. Agustina $\mathrm{R}$,Ahmad WL. Malnutrisi dan Kaitannya Dengan Status Imunitas Lanjut
Usia. Majalah Gizi Medik Indonesia. 2003;2(6):16-28.

33. Cereda, E. The Association of Geriatric Nutritional Risk Index and Total Lymphocyte Count with Short-Term Nutrition- Related Complications in Institutionalised Elderly. Journal of the American College of Nutrition 2008;27(3):406-413.

34. Gariballa, S. Nutrition and Older People: Special Considerations Relating to Nutrition and Ageing. Clin Med 2000; 4:411-414.

35. Ahluwalia, N. Nutrition And Immune Function. J Nutr Health Aging. 2004; 8:26.

36. Kuzuya M, Kanda S, Koike T. Lack Of Correlation Between Total Lymphocyte Count And Nutritional Status In The Elderly. Journal of Clin Nutr. 2005;24 :427-432.

37. Izaks GJ, Remarque EJ, Becker SV. Lymphocyte Count And Mortality Risk In Older Persons. J Am Geriatr Soc .2003; 51:1461-1465.

38. Seltzer MH, Bastidas JA, Cooper DM. Instant Nutritional Assessment. Journal Parenter Enteral Nutr. 1979; 3:157-159.

39. Walrand S, Moreau K, Caldefie F. Specific and Nonspecific Immune Responses To Fasting and Refeeding Differ In Healthy Young Adult and Elderly Persons. Am J Clin Nutr. 2001;74:670-678.

40. Asiah, N. Nutrisi, Infeksi dan Imunitas: Suatu Sinergisme. Majalah Gizi Medik Indonesia 2003; 2 (6): 6-12.

41. Fatimah, N .Malnutrisi Di Rumah Sakit. Majalah Gizi Medik Indonesia 2002, 1 (1):4-6.

42. Nishida, T. Low Lymphocyte Count In Underweight Japanese Women. Environ Health Prev Med. 2008; 13:345-348.

43. Budiarto, E. Metodologi Penelitian Kedokteran. Jakarta: EGC ,2004.

44. World Health Organization. Physical Status: The Use And Interpretation Of Anthropometry. Technical report series. Geneva: WHO, 1995.

46. Dahlan, S. Statistik untuk kedokteran dan kesehatan Edisi 4. Jakarta: Salemba Medika, 2009. 